\title{
Professionalization of Public Buyers: Determining Primordial Effectiveness of Public Order
}

\author{
Abdelkader El Amry, (PhD student) \\ Ibn Tofail University / Faculty of Economic and Social Juridical Sciences - \\ Kenitra, Morocco
}

\section{Doi:10.19044/esj.2018.v14n22p54 URL:http://dx.doi.org/10.19044/esj.2018.v14n22p54}

\begin{abstract}
The professionalization of the actors of the purchasing process has now become an essential priority for the optimization of state purchases, especially since the public order now stands at $195 \mathrm{MMDH}$, equivalent to $17.4 \%$ of GDP. Public procurement is a very sensitive area since, very often, the stakes are of such a magnitude that they have an impact on the economy, the political, the social and the environment. To this end, the professionalization of public buyers remains in Morocco, one of the ways to reduce the risks and the negative consequences in the awarding of contracts. This is why, today, more and more public administrations are called upon to resort to competent public purchasers in the field of knowledge management regarding the regulation of public contracts in order to improve their missions. To inquire about the veracity of the contribution of the professionalization of the public purchasers to the efficiency of the public order. This investigation was undertaken in the form of a questionnaire filed with 06 sub-ordonnateurin the city of Meknes. The aim is to inquire about the relationship between the professionalization of public purchasers and other three determinants, namely: a) e-procurement , b) transparency, and c) the free play of competition, and how they commonly contribute to the efficiency of the public order. The result of this article reveal that the professionalization of public buyers is a key determinant of the efficiency of public procurement.
\end{abstract}

Keywords: Competition, Efficiency, E-procurement, Professionalization, Transparency

\section{Introduction}

Public procurement is governed by rules, norms and procedures the application of which rests on individuals. The human factor plays a crucial role in this operation because the process can not be completely automated. Literally, human intervention in the process opens the door to all kinds of 
eventualities in awarding markets. Without presumption, people in charge can, consciously or unconsciously, voluntarily or involuntarily, under influence or not, with or without competence, modify the trajectory of a project during the acquisition of goods or services or in the construction of an infrastructure. Henceforth, the consequences of the public administration can be either positive or negative.

In order to properly manage the role of public purchaser and to ensure that public procurement officials are competent, aware of professional ethics, and occupy the position by merit and not by other considerations (membership political, clientelism, favoritism,among others), the Moroccan government has decided to professionalize this operationby launchingthe pact of Good Governance in 1995 (as cited in Beth \& Hrubi)assuming that the improvement of administration could fulfilled through the rationalization of the public management, the moralization of the administration, and the opening of the administration for to all citizens. Actually, well qualified and competent staff of public procurement remains a prerequisite to achieveeffecient governance of public procurement.In this perspective, the professionalization of public purchasers essentially rests on the extent to which working skills and regulationsare developed and understood.

Nevertheless, the undermining of professionalization of public purchasers has always been considered one of the obstacles that empedes the development of a transparent and an efficient system of public procurement in Morocco, both by the public purchasers themselves and by the industry, being it public or private.

To this end, in order to mitigate this the impact of this procedure, public actorsarenotified to develop specific training activities for public purchasers in order to guarantee better management of public funds. Recently, many Moroccan public institutions have taken outstanding multidisciplinarymeasures inherent in the profession of public purchaser to distinguish between the legal competences required to secure procedures and those that are more economical which allow the public purchaser to determine the most efficient procedure.

In practice, public purchasers in the strict sense of the term should be either highly qualified professionals or must giventhem the possibility of becoming so by the institutions that employ them.

Zero risk will never exist in the field of public order because of the human factor which should be restrainedand controlled.For this purpose, the public purchaser, prequisite to public order operations, plays premordial role to successefully manage public order for the following reasons:

- To ensure the best price and quality conditions for the purchases to be made, 
- To contribute to the performance and efficiency of the public order while ensuring the security of the

procurement and execution procedures by anticipating litigation risks.

- To ensure the best quality and/or price ratio inrder to face budget restrictions.

- To acquire a global vision which combine legislation, functional analysis, culture of the performance, and

management of the execution.

In this context, the present studyattempts to examine the extent to which the professionalization of public purchasers participate in the consecration of the efficiency practices of the public order.

\subsection{Professionalization in the Context of the Public Order}

Professionalization which is at the heart of political concerns raises many concerns in both workplace and training contexts due to its omnipresence in discourse and practice. In this sense, Wittorski (2008) mentions that the concept of'professionalization' appeared in different places at different times. Since the end of the nineteenth centuary, Wittorski claims that the concept, which started in France, was used by social groups, companies and training circles to signify various intentions that can be listed under the following elements:

- The constitution of an autonomous social group : Professionalization as constitution of professions.

- A support for work flexibility: Professionalization as a means to achieve work efficiency.

- A process to prepare professionals through training: Professionalization-training. (p.15)

Moreover, Rey (as cited in Barraud, 2013), stipulates that 'Professionalization', which is an Englishword, emanates from functionalist sociology to designatean action the fulfillmen of which necessitate the mastery of a professional activity. For Rey, the concept of professionalizationis often opposed to the concept of qualification since it is often associated with the notion of competence.

To strengthen the integrity as well as to improve the performance of the public procurement systems, civil actors working in the public procurement field must have full professional status. To this end, the Organization for Economic Co-operation and Development (OECD) (2010) recommends that:

Granting civil servants working in the field of public procurement the status of a profession in their own right is essential to better resist mismanagement. , waste and corruption. Governments should invest accordingly in public procurement and provide adequate incentives to attract highly qualified public servants. 
They should also ensure that the knowledge and skills of relevant officials are regularly updated to reflect regulatory, managerial and technological developments. Public servants should be aware of the standards of integrity, and be able to identify any potential conflict between their private interests and their public missions, which may influence public decision-making. (p.36)

Based on the condition mentioned in (OECD, 2010), public procurement executives will be able to avoid mismanagement, waste, and resist the temptations of corruption. To ensure this operation, public administrations should focus on providing the public procurement sector with adequate incentives to attract highly qualified candidates to the profession. Additionally, public officials in charge of public procurement should constantly update their knowledge and skills in order to take into account the requirements of regulations and technologies adopted for this aim. According to the OECD (2010), the professionalization of actors depends on the mobility of public executives, exchanges between the public and private sectors for a mutual enrichment of talents, and professional know-how.

\subsection{Definition of Professionalization}

Finding An inclusive definition for the concept of professionalization is not an easy task due to its polysemouse meaning. To explain this term, several definitions are available to grasp its meaning. For instance, Barrier (as cited Lac \& Ratinaud, 2005) maintain that professionalization needs to be defined within the Anglo-Saxon and Francophone context. In the Anglo-Saxon setting, Barrier assumes that it refers to "the process of birth and structuring of organized groups, autonomous, and defending their interests, in particular by controlling access to the profession and its exercise" (p.68). However, Barrier adds that the french definnition of the term refers to the training of human resoursesand their integrationin a given profession in the field. In fact, the french approach underpins that the operation must be built on criterion of change, evolution, structuring of specific knowledge, as well as the dimension of reflexivity on practices.

In the same direction, Sorel (as cited in Barraud, 2013, p.19) posits that professionalization corresponds to a stated intention that brings individuals and work situations together in order to allow the articulated development of skills and action processes specific to situations concerned. The work by Sorel acknowledges that professionalization is actually a strategy to transform knowledge which requires recognition by individuals, collectives or organizations (plan of action), professional socialization, and identity transactions. An other definition related to the concept of professionalization is provided by the National Center for Textile and Lexical Resources (NCTLR) (as cited in Kieran, 2013) explains that professionalization is "the 
state, the character of what is made professional, becoming a professional"(p. 4). Moreover, the Public Interest Grouping (GIP) (2013), called also ALFA CENTER, defines professionalization as a process which brings together all the actions and approaches that allow professional activities in emergence and construction to become a real profession, to enroll in professional courses and to be recognized in training standards, qualification and professional certification.

Finally, it could be deduced that professionalisation as part of the public order brings together all the training skills knowledge and experiences held by public buyers in the field of public procurement. Also, it allows thgem to control the management of public expenditure and develop consistent and effective public purchasing strategies to promote the a booming business of public purchaser, which combines operational, legal, and economic expertise. In other words, professionalization of public buyers remains a very specialized, qualified, autonomous concept driven by values of commitment and responsibility in the area of public procurement.

\subsection{The Objectives of Professionalization in Public Procurement}

In a context marked by profound changes in the domain of public procurement, the professionalization of public buyers in Morocco has become a substantial necessity, to efficiently purchase functions, involved in strategic projects based on the accession of all services. In this perspective, mastering management techniques in public procurement is essential to ensure the implementation of public procurement procedures for the purpose of legal security and economic efficiency. To this end, professionalization aims to achieve the following objectives:

First, it attempts to optimize public purchases within the framework of a total respect of the fundamental principles of the public orderamong all public purchasers of the public service. For instance, the levers of optimization of purchases can be activated by public buyererson the level of a fair competition, the reinforcement of transparency, the precise and exact definition of needs, the management of suppliers panel, the benchmarking of performances, and the rationalization of cash flows. Second, professionalization aims to promote buyers capabilities to rationalize purchases via the reinforcement of their competences according to the functions mentioned in Héron (2013).

- Regulatory function: knowledge of public procurement procedures, control of the design and monitoring of markets, control of the tendering regulatory process, control of the legal watch.

- Economic function:this element stands for control of the analysis of the need, control of the negotiation, techniques of the purchase, the supply, the concepts of price and their evolution, of the economic 
watch, and control of the concepts of control of management applied to the purchase.

- Financial function: mastering the concepts of managing a budget, mastering the accounting process.

- Management function: mastering the strategic concepts of the purchasing function, the purchasing organization process and the purchasing management process.

On equal basis, professionalization develops the skills of public buyers to internalize public procurement management techniques according to the following principles :

- Total control of public procurement regulations;

- More polyvalence (identification of needs, development of specifications, negotiation skills, market monitoring, market engagement, market scheduling, among others.

- Increased ability to adapt with new information and communication technologies (e-procurement, integrated expenditure management system)

- Greater autonomy and decision-making in situations of uncertainty.

- Rapidity to react to different situations such as litigation (termination, litigation and conflicts, among others.

To wrap up, it follows from the above arguments that the professionalization of public purchasers is mandatory in public administrations to control and optimize spendings.

\subsection{E-Procurement is a Catalyst to the Professionalization of Public Purchasers}

The decree $n{ }^{\circ} 2-12-349$ of 8 joumada Ier 1434 (March 20, 2013) relative to the public markets equipsmarkets managers with legal tools to help them fulfill their missions and get best results, namely the integration of 'eprocurement', the use of a common platform called 'integrated expenditure management system' as a new instrument to facilitate processing of files and the exchange of information between public buyers and the Kingdom's General Treasury.

The intended purpose behind the introduction of these instruments for the benefit of the public purchaser whose strategic objectives are the consecration of the transparency of procedures, is to simplify procedures and to modernize public expenditure execution processes on the one hand, and to the perpetualy develop a more coherent and efficient public purchasing strategy that favors the booming business of public purchasers on the other hand.In this context, Boutaqbout (2008) argues that the public purchaser is gradually becoming a real manager as he/she takes into account new parameters, such as the scheduling of purchases knowledge of suppliers, and the faculty of negotiate 
during the consultation when the 'Code des Marches Publics' allows it.Being aware of these responsabilities, public buyers guarantee the effectiveness of the public order and the preservation of public funds by respecting the principles underpinning the public order.

\section{Empirical study on the professionalisation of public purchasers}

The public order is based on fair competition, transparency ,and eprocurement.The questionnaire proposed in this study aims to confirm, to reverse or even evaluate the extent to which the professionalization of public purchasers participate in the consecration of efficiency practices of the public order. Above all, it should made clear that efficiency of public order indissociablybrings together four compulsory principles including a)theeprocurement of the public order, b) professionalization of public purchasers, c) transparency, and d) the free play of competition.

The ranking of these elements is not arbitrary, but it is dictated by the importance of each single phase involved in the process of e-procurement. Indeed, e-procurement, which is an principle to illustrate the country's determination,is neceessary to ensure transparency and fight against corruption. Furthermore, it is an effective method to increase transparencyand competition since itlargely contributes to the professionalism of managers by allowing them better management and masteryof computer techniques.To ensure the reliability and the importance of the variables to the effectiveness of public procurement, an empirical study survey was conducted based on a questionnaire that was distribute to six sub-contractors who are highly qualified in the field in the city of Meknes, Morocco. Actually, the respondents were asked to answer questions related manly to the contribution of the professionalization of the public purchasers to the efficiency of the public order. More particularly, the respondents wre aske to objectively react to the relationship between the professionalization of public purchasers and the other determinants, namely, e-procurement, transparency, free play of the competition, and finally to state clearely how these elementscommonly contribute to the efficiency of public procurement. The results of the study as revealed in the table below show that the professionalization of public purchasers is indeed an inescapable determinant of the efficiency of the public order. Additionally, the results postulate that all sub-ordinators admit that professionalisation of public purchasers is an unavoidable tool to realize the other parameters namely e-procurement, transparency, and competition. Finally, the respondendents recognize that the four determinants, when combined, contribute to the efficiency of the public order. 
Table 1:Matrix of passage relating to professionalization

\begin{tabular}{|c|c|}
\hline Question & Percentage \\
\hline $\begin{array}{l}\text { 1. Do you think that the professionalization of public purchasers can } \\
\text { improve the consecration and efficiency practices related to the public } \\
\text { order? }\end{array}$ & $100 \%$ \\
\hline $\begin{array}{l}\text { Does the professionalization of public buyers contribute to an easy use } \\
\text { of a paperless public order platform? }\end{array}$ & $100 \%$ \\
\hline $\begin{array}{l}\text { 3. Do you think that the professionalization of public buyers contributes } \\
\text { to achive transparency of public order? }\end{array}$ & $100 \%$ \\
\hline $\begin{array}{l}\text { 4. Do you think that the professionalization of public purchasers } \\
\text { guarantees the free play and the reinforcement of the competition of } \\
\text { the public order? }\end{array}$ & $100 \%$ \\
\hline $\begin{array}{l}\text { 5. Do you think that the professionalization of public purchasers is an } \\
\text { effective means to reach of e-procurement, transparency, and } \\
\text { competition? }\end{array}$ & $100 \%$ \\
\hline
\end{tabular}

\section{Conclusion}

One of the key deficiencies inherent to the Decree No. 2-12-349 of 8 July 1434 (20 March 2013) on public procurement is the neglect of rofessionalization of public purchasers. To this end, the Moroccan government needs to reconsider the concept of professionalizion related to the the procurement system, notably by including public procurement courses as a topic in administrativetop management training schools by defining the real objective behind the selection of procurement staff in terms of training and experience, and professionalizing complementary trades, particularly those involved in monitoring and controlling the execution of contracts.

Eventually, the present study recommends that procurement must be considered a strategic activity, rather than a mere administrative function. This maye enable public procurement staff to impprove the skills, experiences, and current qualifications to prevent the risks of mismanagement and corruption. Thus, qualification conditions must be well oriented and training actions relating to new technologies or specific situations, such as the awarding of contracts of an urgent nature.

\section{References:}

1. Barraud, C. (2013). Professionnalisation des étudiants infirmiers et construction identitaire : une approche par les représentations $d u$ métier et sous l'angle de la catégorisation sociale inter IFRSI[Professionalization of nursing students and identity construction: an approach by the representations of the profession and from the angle of the social categorization inter IFRSI]. (Thèse de Doctorat). Université de Bordeaux, France. Disponible sur file://C:/Users/USER/Downloads/These_Catherine_Barraud.pdf 
2. Beth, E., \& Hrubin, A. (2008). Renforcer l'intégrité dans les marchés publics : Etude d'apprentissage mutuel au Maroc [Strengthening Integrity in Public Procurement: Mutual Learning Study in Morocco]. Document interne, Direction de la Gouvernance publique et du développement territorial. OCDE, Paris. Disponible sur http://www.oecd.org/governance/ethics/41548926.pdf.

3. Boutaqbout, A. (2008). Le management des marchés public au Maroc [Public Procurement Management in Morocco]. (Mémoire du Cycle Supérieur de Gestion). Institut Supérieur de Commerce et D’Administration des Entreprises, Casablanca, Maroc

4. Décret $n^{\circ} 2-12-349$ du 8 joumada Ier 1434 (20 mars 2013) relatif aux marchés publics

5. GIP ALFA CENTRE, La Professionnalisation, Région Centre, 2013, http://www.alfacentre.org/lr_ncnq/PROFESSIONNALISATION/Pro fessionnalisation.htm,

[En Ligne], [Consulté le 12/03/2013]

6. Héron, J.M. (2013). Le métier d'acheteur, selon l'association des acheteurs publics[The buyer's profession, according to the association of public purchasers]. Disponible surhttp://www.aapasso.fr/upload/aact_dans_la_presse/20131024_met ier_acheteur_d_apres_lAAP.pdf

7. Kieran, P. (2013). Quid de la professionnalisation des infirmiers et des infirmières. [What about the professionalization of nurses]. (Mémoire de fin d'études UE 5.6 S6). Institut Formation en Soins Infirmiers, Rambouillet, France.

8. Lac, M., \& Ratinaud, P. (2005). La professionnalisation approche d'un processus représentationnel. Journal International sur les Représentations Sociales, 2(1), 68-75.

9. Organisation de Coopération et de Développement Economique (OCDE). (2010). Principe de l'OCDE pour renforcer l'intégrité dans les marchés publics[OECD Principle to Strengthen Integrity in Public Procurement]. Edition : OCDE.

10. Rey, A. (1998). Dictionnaire historique de la langue française. Le Robert. P17

11. Wittorski, R. (2008). La professionnalisation [Professionalization]. Revue Savoirs, 17, 9-36. 